\title{
STUDI KOMPARASI KUALITAS DAYA ANTARA PEMBANGKIT LISTRIK TENAGA SURYA (PLTS) DENGAN PEMBANGKIT GENSET DENGAN DAYA SAMA 15KVA
}

\author{
Hartono B.S.' dan Budiyanto ${ }^{2}$ \\ 1) Jurusan Teknik Konversi Energi - Politeknik Negeri Bandung \\ ${ }^{2)}$ Jurusan Teknik Elektro - Universitas Muhamadiyah Jakarta \\ Email : ${ }^{1)}$ hartono@esi-labs.com ${ }^{2)}$ yan.budiyanto@yahoo.com
}

\begin{abstract}
Abstrak
Pembangkit Listrik Tenaga Surya (PLTS) memanfaatkan radiasi matahari sebagai sumber energi yang dikonversi menjadi energi listrik menggunakan perangkat sel surya (photovoltaic). Tegangan DC dari sel surya akan dirubah menjadi listrik tegangan AC menggunakan perangkat konverter DC-AC atau dikenal sebagai perangkat inverter. PLTS juga dapat dioperasikan bersama sumber energi lain dalam mensuplai daya listrik, baik dengan energi angin atau menggunakan pembangkit konvensional, konfigurasi ini dikenal sebagai PLTS Hibrid. Generator set atau genset pada sistem PLTS hibrid digunakan sebagai sumber energi listrik pengganti ketika tidak ada tenaga listrik yang dihasilkan dari PLTS atau ketika listrik di dalam baterai minimum, generator diesel akan bekerja untuk menghasilkan listrik yang diperlukan. Genset juga digunakan untuk mensuplai beban-beban prioritas.

Bagaiman kualitas daya keluaran dari PLTS jika dibandingkan dengan daya keluaran dari genset sehingga kedua sistem ini dapat dioperasikan secara hibrid menjadi topik kajian yang dilakukan dalam penelitian ini.
\end{abstract}

Kata kunci : PLTS, hibrid, Genset, Sel Surya, inverter, kualitas daya

\section{PENDAHULUAN}

Energi terbarukan merupakan energi yang berasal dari sumber daya alam terbarukan seperti air, cahaya matahari, angin, dan panas bumi. Seiring dengan meningkatnya kebutuhan energi yang digunakan oleh manusia setiap tahunnya membuat konsumsi energi mengalami kenaikan yang cukup besar, salah satu bentuk energi yang banyak dikonsumsi oleh kehidupan manusia adalah energi listrik. Oleh karena itu energi listrik mengalami kenaikan dan menjadi sumber utama kehidupan bagi manusia.

Radiasi matahari merupakan sumber energi terbarukan yang tidak akan pernah habis jika digunakan, energi ini tidak akan menimbulkan polusi terhadap lingkungan seperti pembangkit listrik lain. Pembangkit Listrik Tenaga Surya (PLTS) memanfaatkan radiasi matahari sebagai sumber energi yang akan dikonversi menjadi listrik menggunakan perangkat photovoltaic/sel surya. Tegangan listrik DC dari sel surya akan dirubah menjadi tegangan listrik $\mathrm{AC}$ menggunakan perangkat konverter DC-AC atau dikenal sebagai perangkat inverter. PLTS juga dapat dioperasikan bersama sumber energi lain dalam mensuplai daya listrik, baik dengan energi angin atau menggunakan pembangkit konvensional, konfigurasi ini dikenal sebagai PLTS Hibrid[1][2].

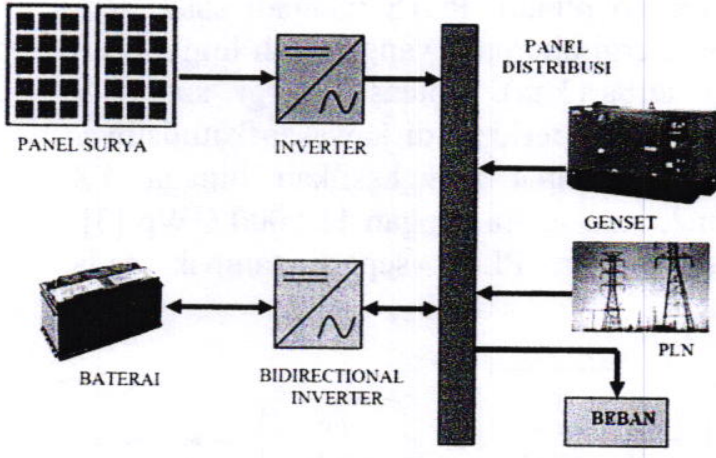

Gambar 1. Diagram Pembangkit Listrik Tenaga Surya Hibrida

Jika sumber listrik ini akan langsung digunakan maka harus dirubah terlebih dahulu oleh inverter menjadi sumber AC, itu dikarenakan jenis beban yang digunakan adalah sumber listrik AC. Jika sumber energi ini tidak digunakan maka akan disimpan ke dalam baterai dengan melewati bidirectional inverter. Jika suplai yang dihasilkan dari matahari tidak dapat mensuplai kebutuhan beban yang ada maka kekurangan ini akan diambil dari baterai melalui 
bidirectional inverter tersebut. Pada saat suplai masih tetap tidak mampu memenuhi kebutuhan beban maka suplai listrik akan diambil dari genset (generator set) untuk mensuplai energi listrik.

Generator set atau genset pada sistem PLTS hibrid digunakan sebagai sumber energi listrik pengganti ketika tidak ada tenaga listrik yang dihasilkan dari PLTS atau ketika listrik di dalam baterai minimum, generator diesel akan bekerja untuk menghasilkan listrik yang diperlukan. Genset digunakan untuk mensuplai beban-beban prioritas, beban puncak atau untuk pengisian baterai.

Bagaiman kualitas daya keluaran dari PLTS jika dibandingkan dengan daya keluaran dari genset sehingga kedua sistem ini dapat dioperasikan secara hibrid menjadi topik kajian yang dilakukan dalam penelitian ini.

\section{METODOLOGI}

\section{PLTS}

Pembangkit Listrik Tenaga Surya, PLTS, adalah pembangkit listrik yang menghasilkan energi listrik dari radiasi matahari (energi surya) yang dikonversi menjadi listrik menggunakan panel surya (photovoltaic). PLTS menjadi salah satu sumber energi alternatif yang ramah lingkungan (energi terbarukan). Potensi energi surya di Indonesia yang terletak di kawasan katulistiwa, diperkirakan dapat menghasilkan hingga 4.8 $\mathrm{KWh} / \mathrm{m} 2$, atau setara dengan $112.000 \mathrm{GWp}$ [3]. Diagram sistem PLTS seperti tampak pada gambar 2.

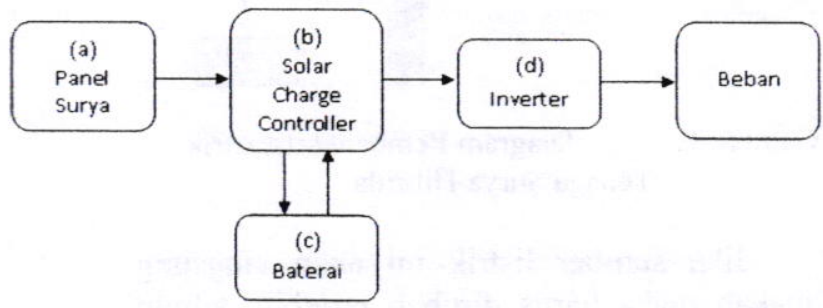

Gambar 2. Diagram sistem PLTS

\section{Energi Matahari}

Radiasi merupakan energi cahaya matahari yang jatuh pada permukaan bumi, besar radiasi ini dalam $\mathrm{W} / \mathrm{m}^{2}$ dengan besar radiasi maksimum yaitu $1000 \mathrm{~W} / \mathrm{m}^{2}$. Lamanya matahari bersinar dalam satu hari dan satu musim akan mempengaruhi jumlah energi yang jatuh pada permukaan datar di permukaan bumi. Jika permukaan satu meter persegi dimiringkan dan menjadi tegak lurus terhadap arah datang sinar matahari akan membuat densitas energi yang diterima akan semakin bertambah.

Radiasi yang mencapai permukaan bumi terdiri dari radiasi langsung (direct radiation) dan radiasi tersebar (diffusion radiation). Radiasi tersebar tidak sebesar radiasi langsung, tetapi masih dapat menghasilkan energi panas untuk kolektor dan energi listrik untuk panel surya.

\section{Panel Surya}

Panel surya terdiri dari beberapa sel surya yang digabungkan secara seri ataupun paralel yang digunakan untuk merubah radiasi mayahari menjadi energi listrik. Sel surya merupakan bahan semikonduktor dalam bentuk dioda sambungan PN yang mampu menciptakan energi listrik melalui proses pemutusan ikatan elektron pada atom-atom dalam kristal semikonduktor ketika ditambahkan sejumlah energi. Ada beberapa jenis sel surya, antara lain : Monocrystalline silicon, Polycrystalline silicon, dan Amorphous silicon [4].

Total radiasi matahari adalah daya radiasi yang dihasilkan oleh matahari per luas penyinaran yang mengenai panel surya dengan satuan $\left(\mathrm{W} / \mathrm{m}^{2}\right)$. Untuk menghitung daya listrik yang dibangkitkan oleh matahari pada panel surya yaitu:

$\mathrm{P}=\mathrm{A} \times \mathrm{G}$

Keterangan :

- $\quad \mathrm{P}=$ Daya yang dibangkitkan oleh panel surya (Watt)

- $\quad \mathrm{A}=$ Luas panel $\left(\mathrm{m}^{2}\right)$

- $\mathrm{G}=$ Radiasi total matahari $\left(\mathrm{W} / \mathrm{m}^{2}\right)$

Untuk PLTS yang ada di laboratorium surya mempunyai lebih dari satu panel sehingga :

$\mathrm{P} \quad=\mathrm{A} \times \mathrm{G} \times \Sigma$ panel

dengan, $\Sigma$ panel adalah jumlah panel surya

\section{Solar Charge Controller}

solar charge controller (SCC) digunakan untuk mengatur daya keluaran panel surya. Ketika daya yang dihasilkan panel surya tidak 
memenuhi untuk mensuplai beban maka SCC akan menambahkan daya dari baterai mensuplai beban. Sementara ketika daya keluaran panel surya melebihi kebutuhan beban maka sisa daya yang dihasilkan oleh SCC akan digunakan untuk untuk mengisi baterai, akan tetapi ketika baterai penuh maka SCC akan mengatur daya keluaran panel sehingga sesuai dengan kebutuhan beban [5]. Baterai yang digunakan untuk menyimpan daya yang dihasilkan oleh panel surya bertipe Deep cycle battery, digunakan sebagai sistem penyimpanan off grid pada PLTS.

\section{Inverter}

Pada PLTS Inverter digunakan sebagai konverter yang merubah tegangan DC keluaran dari panel surya menjadi tegangan AC yang sesuai untuk mensuplai beban AC. Jenis inverter ada 2 yaitu Isolated inverter dan grid inverter. Isolated inverter digunakan ketika hanya mensuplai beban yang tidak terhubung dengan jaringan listrik PLN. Grid inverter digunakan ketika beban yang disuplai terhubung ke jaringan PLN. Kualitas inverter juga dapat dilihat dari keluaran yang dihasilkan. Ada tiga jenis keluaran tegangan inverter yaitu :

- Square wave inverter

- Modified square wave inverter

- Pure sine wave inverter

Kualitas daya keluaran dari pembangkit hibrid dapat dilihat dari kemampuan menyalurkan daya aktif, daya reaktif dan faktor daya ke beban[6].

\section{Daya aktif}

Daya aktif adalah daya sebenarnya yang dibutuhkan oleh beban. Parameter ini dinyatakan dalam satuan Watt.

$\mathrm{P}_{1 \Phi}=\mathrm{V}_{\mathrm{L}-\mathrm{N}} \mathrm{x} \mathrm{I} \times \cos \varphi$

$P_{3 \Phi}=3 \times V_{L-N} \times I \times \cos \varphi$

Keterangan:

$\mathrm{P} \quad=$ Daya aktif $(\mathrm{W})$

$\cos \varphi=$ Faktor daya

\section{Daya reaktif}

Daya reaktif adalah daya yang dibutuhkan untuk mengoperasikan beban induktif. Parameter ini dinyatakan dengan satuan VAR.

$$
\begin{aligned}
& \mathrm{Q}_{1 \Phi}=\mathrm{V}_{\mathrm{L}-\mathrm{N}} \times \mathrm{I} \times \sin \varphi \\
& \mathrm{Q}_{3 \Phi}=3 \times \mathrm{V}_{\mathrm{L}-\mathrm{N}} \times \mathrm{I} \times \sin \varphi
\end{aligned}
$$

Keterangan:

$\mathrm{Q} \quad=$ Daya reaktif $(\mathrm{VAR})$

$\sin \varphi \quad=$ Faktor daya

\section{Faktor Daya}

Faktor daya adalah hasil bagi antara daya aktif (kW) dengan daya nyata (kVA), yang

dinyatakan dalam persamaan :

$\mathrm{PF}=\frac{\mathrm{P}(\mathrm{kW})}{\mathrm{S}(\mathrm{kVA})}$

Keterangan :

$\mathrm{P}=$ Daya aktif $(\mathrm{kW})$

$\mathrm{S}=$ Daya semu $(\mathrm{kVA})$

Besar kecilnya faktor daya dipengaruhi oleh daya reaktif yang merupkan daya tidak berguna karena tidak dapat dirubah menjadi tenaga, akan tetapi diperlukan untuk proses transformasi energi pada beban induktif, misalnya transformator atau motor induksi. Dalam teori listrik arus bolak-balik penjumlahan daya dilakukan secara vektoris, yang dibentuk vektornya merupakan segitiga siku-siku yang dikenal dengan segitiga daya, Gambar 3. Sudut $\varphi$ merupakan sudut pergeseran fasa.

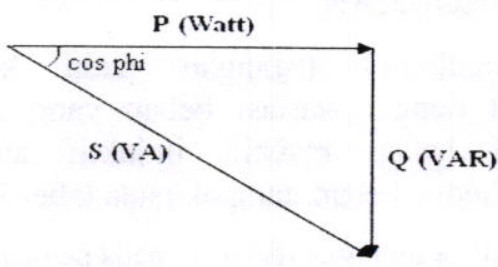

Gambar 3. Diagram Segitiga Daya

\section{Beban}

Beban merupakan peralatan listrik yang menerima daya listrik. Beban ini terbagi menjadi tiga yaitu :

a. Beban resistif adalah beban yang hanya menerima daya aktif dan mempunyai faktor daya sebesar 1. Beban resistif seperti lampu pijar, pemanas yang menggunakan elemen resistor dan lainnya.

b. Beban induktif terdapat pada motor induksi dan transformator akan menarik daya aktif dan reaktif. Daya aktif untuk membangitkan 
daya poros pada motor induksi sedangkan daya reaktif sebagai daya magnetisasi alat tersebut.

c. Beban kapasitif seperti kapasitor bank yang dapat menghasilkan daya reaktif.

\section{Metode Pengujian}

Pada pengujian yang dilakukan untuk melihat perbandingan kinerja dari kedua pembangkit yaitu PLTS dan Genset, maka dilakukan pengukuran pada parameter tegangan, daya VA dan faktor daya $(\cos \Theta)$ dengan beban yang diberikan mulai dari beban resistif, induktif dan gabungan antara beban resistif-induktif. Kedua pembangkit memiliki keluaran tiga fasa dengan spesifikasi kedua pembangkit yang digunakan seperti tampak pada tabel 1. Pada pengujian ini besaran radiasi dan laju aliran daya pada bagian DC tidak dilakukan pengukuran.

Tabel 1. Daya dan kapasitas Energi dari Setiap Komponen Sistem PLTS dan genset

\begin{tabular}{|l|c|}
\hline \multicolumn{1}{|c|}{ Komponen Sistem } & Daya dan Energi \\
\hline Panel Surya & $18 \mathrm{~kW}$ \\
\hline Baterai & $60 \mathrm{kWh}$ \\
\hline Inverter & $18 \mathrm{~kW}$ \\
\hline Bidirectional Inverter & $15 \mathrm{~kW}$ \\
\hline Generator Set & $12,35 \mathrm{~kW}$ \\
\hline
\end{tabular}

\section{HASIL PENGUJIAN}

Hasil pengukuran tegangan pada kedua pembangkit dengan variasi beban yang sama baik pada beban resistif, induktif ataupu kombinasi kedua beban, tampak pada tabel 2 .

Tabel 2. Hasil pengukuran tegangan pada pembangkit PLTS dan GENSET

\begin{tabular}{|c|c|c|c|c|c|c|}
\hline \multirow{2}{*}{ Beban } & \multicolumn{3}{|c|}{ Volt (PLTS) } & \multicolumn{3}{|c|}{ Volt (GENSET) } \\
\hline & $\Theta 1$ & $\Theta 2$ & $\Theta 3$ & $\Theta 1$ & $\Theta 2$ & $\Theta 3$ \\
\hline R0 & 399,2 & 400,4 & 398,7 & 233,6 & 228,3 & 231,8 \\
\hline R1 & 230,1 & 230,1 & 230,1 & 233,6 & 228 & 232,1 \\
\hline $\mathbf{R} 2$ & 230 & 230,5 & 230,5 & 233,7 & 227,8 & 232,4 \\
\hline L1 & 229,6 & 230,3 & 230 & 233,8 & 227,9 & 231,8 \\
\hline L2 & 228 & 228,6 & 228,3 & 233,7 & 228,2 & 231,5 \\
\hline R1L1 & 229,3 & 229,6 & 229,5 & 231,1 & 231,9 & 231,6 \\
\hline R1L2 & 227,7 & 228,3 & 228,1 & 233,3 & 229 & 234,6 \\
\hline R2L1 & 229,2 & 229,7 & 229,6 & 233,8 & 228,1 & 231,9 \\
\hline R2L2 & 227,7 & 228,3 & 228,2 & 233,1 & 227,9 & 231,7 \\
\hline
\end{tabular}

$R 0=$ Terbuka/tanpa beban, $R I=200 \Omega, R 2=80 \Omega$,

$L 1=20 \mathrm{mH}, L 2=60 \mathrm{mH}, \Theta=$ fasa.

Hasil pengujian menunjukan kedua pembangkit memberikan nilai tegangan yang hampir sama, hanya saja pada saat beban 0 pada PV nilai tegangan menunjukan nilai tegangan sebesar $400 \mathrm{~V}$ sementara pada Genset menunjukan tegangan keluaran disekitar $230 \mathrm{~V}$. Pada PV nilai tegangan keluaran relatif hampir sama pada setiap fasanya, sementara pada genset perbedaan tegangan antar fasanya lebih lebih besar.

Tabel 3. Hasil pengukuran daya keluaran pada pembangkit PLTS dan GENSET

\begin{tabular}{|c|c|c|c|c|c|c|}
\hline \multirow{2}{*}{ Beban } & \multicolumn{3}{|c|}{ kVA (PLTS) } & \multicolumn{2}{c|}{ kVA (GENSET) } \\
\cline { 2 - 7 } & $\Theta 1$ & $\Theta 2$ & $\Theta 3$ & $\Theta 1$ & $\Theta 2$ & $\Theta 3$ \\
\hline \hline R0 & 0 & 0 & 0 & 0 & 0 & 0 \\
\hline R1 & 1 & 1 & 1 & 1 & 1 & 1 \\
\hline R2 & 2,1 & 2,1 & 2 & 2,1 & 2,1 & 2,1 \\
\hline L1 & 0,4 & 0,5 & 0,5 & 0,5 & 0,5 & 0,5 \\
\hline L2 & 1,3 & 1,4 & 1,4 & 1,4 & 1,4 & 1,4 \\
\hline R1L1 & 1,1 & 1,2 & 1,1 & 1,1 & 1,2 & 1,2 \\
\hline R1L2 & 1,7 & 1,7 & 1,7 & 1,8 & 1,8 & 1,8 \\
\hline R2L1 & 2,1 & 2,2 & 2,1 & 2,2 & 2,1 & 2,1 \\
\hline R2L2 & 2,5 & 2,5 & 2,5 & 2,6 & 2,5 & 2,6 \\
\hline
\end{tabular}

Tabel 4. Hasil pengukuran faktor daya pada pembangkit PLTS dan GENSET

\begin{tabular}{|c|c|c|c|c|c|c|}
\hline \multirow{2}{*}{ Beban } & \multicolumn{3}{|c}{$\cos \phi$ (PLTS) } & \multicolumn{2}{c|}{$\cos \phi$ (GENSET) } \\
\cline { 2 - 7 } & $\Theta 1$ & $\Theta 2$ & $\Theta 3$ & $\Theta 1$ & $\Theta 2$ & $\Theta 3$ \\
\hline \hline \multirow{2}{*}{ R0 } & 0 & 0 & 0 & 0 & 0 & 0 \\
\hline R1 & 1 & 1 & 1 & 1 & 1 & 1 \\
\hline R2 & 1 & 1 & 1 & 1 & 1 & 1 \\
\hline L1 & 0,1 & 0,11 & 0,1 & 0,1 & 0,12 & 0,11 \\
\hline L2 & 0,09 & 0,1 & 0,09 & 0,09 & 0,09 & 0,12 \\
\hline R1L1 & 0,93 & 0,93 & 0,91 & 0,93 & 0,93 & 0,92 \\
\hline R1L2 & 0,65 & 0,66 & 0,64 & 0,65 & 0,65 & 0,65 \\
\hline R2L1 & 0,98 & 0,99 & 0,98 & 0,98 & 0,98 & 0,98 \\
\hline R2L2 & 0,86 & 0,87 & 0,85 & 0,86 & 0,86 & 0,87 \\
\hline
\end{tabular}

Hasil pengukuran daya semu pada kedua pembangkit seperti tampak pada tabel 3 . Menunjukan bahwa dengan nilai beban daya diberikan maka daya keluaran yang dihasilkan 
kedua pembangkit memiliki nilai yang relatif sama, tidak ada perbedaan yang signifikan.

Hasil pengukuran faktor daya pada pada kedua pembangkit memperlihatkan hasil pengukuran yang kurang lebih sama untuk setiap variasi beban yang diberikan.

\section{KESIMPULAN}

Berdasarkan hasil pengujian menunjukkan bahwa kualitas daya yang dihasilkan kedua pembangkit relatif sama baik untuk setiap variasi beban yang diberikan. Hal ini menunjukan subtitusi daya yang akan disalurkan ketika salah satu sumber bermasalah akan memberikan kualitas daya yang sama baik.

\section{DAFTAR PUSTAKA}

[1] Agus Nurrohim,"Pembangkit Listrik Tenaga Hibrid Sebagai Solusi Kelistrikan Di Daerah Terpencil", Jurnal Sains dan Teknologi Indonesia Vol. 14, No. 2, Agustus 2012 HIm.96-103

[2] Samuel L. Abreu9, Sergio Colle, Karime L. Z. Glitz, Ricardo Rüther and Hans Georg Beyer, "Isolated Hybrid PV-Diesel Power Plants Design Method" RIO 3 World Climate \& Energy Event. Brazil :
University of Santa Catarina Lab SolarDepartment of Mechanical Engineering, 2000.

[3] I.N. Setiawan, I.A.D. Giriantari, W.G. Ariastina, dan I.N. Satya Kumara, "Sel Surya Berbasis Pewarna Alami dan Potensi Pengembangannya di Indonesia sebagai Sumber Energi Alternatif yang Ramah Lingkungan", Seminar Nasional Ketenagalistrikan dan Aplikasinya (SENKA), 2015

[4] Jackson, Frank. "Planning and Installing Photovoltaic Systems Second Edition". London : Earthscan, 2008.

[5] Muhammad Suyanto, "Pemanfaatan Solar Cell Sebagai Pembangkit Listrik Terbarukan", Jurnal Teknik (FT Univ. Pancasila), Vol. 27 No. 3 Okt. 2014, Hal. 135-188

[6] Kadir, Abdul. 1982. Energi. Jakarta : UI Press. 